\title{
Św. Jan z Damaszku, Rozprawa Saracena i Chrześcijanina
}

\author{
(Joannes Damascenus, Disputatio Christiani et Saraceni, \\ CPG 8075)
}

\section{Wstęp}

Drugim pismem Jana Damasceńskiego po rozdziale 100/101 De haeresibus $^{1}$, które dotyczy islamu, jest dialog, a w zasadzie rozprawa

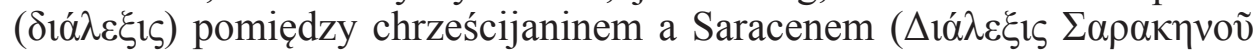

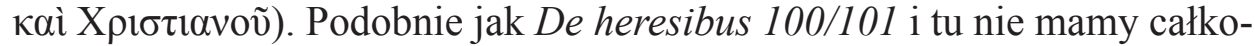
witej pewności co do autorstwa traktatu. Istnieją bowiem dwie redakcje tej dysputy: Lequina i Galendssa. Obie redakcje różnią się kolejnością poruszanych problemów. Według Lequina ostatnia część dysputy została poddana redakcji przez Teodora Abu Qurra. I w tym miejscu uwidacznia się problem autorstwa, ponieważ trudno jest stwierdzić, czy jest to oryginalne dzieło sporządzone przez Jana z Damaszku czy streszczenie dyskusji, które Jan prowadził z saracenami, a dokonane przez Abu Qurrę i błędnie przypisywane Janowi z Damaszku². Nawet pomijając kwestię autorstwa, jest to ciekawe, a zarazem trudne dzieło do poznania wczesnej teologii

1 Odnośnie do numeracji rozdziału O herezji Izmaelitów jako 100/101 należy wiedzieć, że jest ona przyjęta za sugestią D.J. Sahasa, który wykazał w swojej monografii, że w tradycji manuskryptycznej oryginalnie zawartych było 100 herezji. Z numerem 101 pojawia się herezja Izmelitów u Lequina (M. Lequin, Sancti Patris Nostri Joannis Damasceni Monachi et Presbyteri Hierosolymitani. Opera Omniaqueextant, Apud Johannem Baptistam Delessine, Parisiis 1712 - edycja ta zawiera fragmenty greckie) oraz u Migne'a (PG 94, 677-780). Sahas w konkluzji stwierdza, że jeden rozdział O herezji Izmelitów (Islamie) został dodany później. Por. D.J. Sahas, John of Damascus on Islam, the „Heresy of the Ishmaelites”, Brill, Leiden 1972, 51-58. Mając na uwadze te spostrzeżenia, we wprowadzeniu i dalej w tekście stosowana jest numeracja podwójna, czyli 100/101.

2 Por. D.J. Sahas, John of Damascus on Islam, the „Heresy of the Ishmaelites”, Leiden 1972, Brill, 99-102; P. Schalder, The Dialogue between a Saracen and a Christian, 
muzułmańskiej. Na podstawie prowadzonej dysputy można bowiem spróbować śledzić wczesnomuzułmańskie szkoły teologiczne. Niestety, tekst nie zaprezentuje nam w pełni obiektywnie wiadomości, ponieważ jest on autorstwa chrześcijanina, a odpowiedzi Saracena są tylko tłem do jego obszernych wywodów teologicznych.

Sam tekst i przebieg dysputy, a w zasadzie dysput, jest dość skomplikowany. Pozornie jest to jedna dyskusja, jednakże czytający ją odbiorca ma wrażenie pewnego chaosu i nieciągłości myślowej. Zauważalny jest przeskok po pozornie niezwiązanych ze sobą tematach. Miejscami, jak np. w punkcie 1.1., po pytaniu zadanym przez Saracena nie pada od razu odpowiedź, ale następuje wyjaśnienie w formie narracyjnej instrukcji pouczenia, że takie pytanie jest podstępem i należy odpowiedzieć na nie w taki sposób. Sekcja Boża sprawiedliwość (1.1) natomiast w swoim przekazie wprowadza zaburzenie tekstu - przejście z formy dialogu do opisu. Powodem tego stanu jest forma narracji odbiegająca od konwencji tekstu. Przyjęcie formy narracyjnej jest prawdopodobnie zabiegiem redaktora tekstu i ma na celu wyjaśnić lub streścić pewne zawiłości pojawiające się w toku dyskusji obu oponentów. Ogólnie forma pozwala przypuszczać, że sam tekst, o ile może naprawdę zawierać w sobie dużą dozę realizmu zaczerpniętego z prawdziwych dysput, też jest bardziej formą instrukcji dla przyszłych potencjalnych potyczek teologiczno-filozoficznych pomiędzy chrześcijanami a muzułmanami.

Warto zwrócić również uwagę na fakt, że tematy poruszane w trakcie dyskusji szczególnie mają swoje odpowiedniki w dziele Jana z Damaszku, jakim jest Wyktad Wiary Prawdziwej. Dlatego też czytając Rozprawę, warto mieć ten tekst jako kontekst pokazujący spójność myśli teologicznej Jana.

Inną kwestią jest słownictwo, które pozornie wydaje się być powszechnie zrozumiałe. Jednakże przy dogłębniejszej analizie tekstu oryginalnego można zauważyć pewną niedogodność oraz dwuznaczności wypowiedzi Jana. Taka sytuacja, jak można by przypuszczać, jest spowodowana kwestią terminologiczną. Jeśli przyjmie się, że oryginalnym językiem dysput teologicznych pomiędzy chrześcijanami a muzułmanami był język arabski, to zrozumiałe staje się, dlaczego słownictwo tekstu greckiego jest wieloznaczne. Wynika to z potrzeby dopasowania chrześcijańskiej teologicznej terminologii arabskiej ${ }^{3}$, która w czasie życia Jana z Damaszku praktycznie nie istniała, a dopiero stopniowo się rodziła, do ugruntowanej terminolo-

w: Christian-Muslim Relations: A Bibliographical History, t. 1, red. T.R. Thomas - B. Roggema et alii, Laiden - Boston 2009, 295-300.

3 Szerzej na ten temat, por. R. Haddad, La Trinité divine chez les théologies arabes 705-1050, Paris 1985; A. Louth, St. John Damascene, Tradition and orginality in Byzantine Theology, Oxford 2002. 
gii greckiej. Aby lepiej można było zrozumieć głębię teologicznych niuansów, tam gdzie zachodzi taka potrzeba, podane są słowa greckie wraz z ich możliwymi arabskimi odpowiednikami bazującymi na terminologii Koranu, który w ówczesnym czasie mógł być jedynym miarodajnym odnośnikiem do niektórych terminów teologicznych zrozumiałych dla obu stron dyskusji.

\section{Struktura}

W Rozprawie Saracena i Chrześcijanina można wyróżnić następujące tematy: (1) pochodzenie zła, (1.1) Boża sprawiedliwość, (1.2) kreacja a prokreacja, (1.3) zrodzenie Syna przez Ojca, (2) chrzest i zbawienie, (3) wola i tolerancja, (4) Chrystus Bogiem, (5) słowa a komunikacja, (6) wcielenie, (7) unia hipostatyczna, (8) zaśnięcie Maryi, (9) kompletność aktu stworzenia, (10) wyższość Chrystusa nad Janem Chrzcicielem.

Tytuły poruszanych tematów, oznaczane cyfrą rzymską, zostały dodane do tekstu w nawiasach kwadratowych. Podział strukturalny tekstu oryginalnego, oznaczany cyfrą arabską, został zachowany według wydania krytycznego oryginału greckiego.

\section{Treść}

Sama dyskusja rozpoczyna się od kwestii pochodzenia dobra i zła: „Chrześcijanin został zapytany przez Saracena: Kogo uważasz za sprawcę dobra i zła?”. Chrześcijanin, rozpoczynając swoją odpowiedź, mówi, że każdy z natury jest dobry, a nikomu nie zarzuca się zła. Saracen, nie dając za wygraną, stara się zgłębiać temat, zadając kolejne pytanie o sprawcę zła. Na to chrześcijanin odpowiada, że najrozsądniej byłoby wskazać na diabła i samych ludzi. Od tego momentu spirala dyskusji zostaje rozkręcona, ponieważ muzułmanie i chrześcijanie mają przeciwne poglądy na ten temat. Została tu przywołana kwestia wolnej woli człowieka, którą uznają chrześcijanie, lub też predestynacji forsowanej przez muzułmanów. Saracen pyta się więc, czy jeśli człowiek chce czynić zło, to czy to robi? Według chrześcijanina to sam człowiek kształtuje obie natury (tę dobrą i tę złą). Dobro jest nauką Boga jak modlitwa, zło zaś jego zdaniem jest podobne do kradzieży. Chrześcijanin odrzuca naukę, którą głosi ksiega saracena. Jest 
w nim bowiem jego zdaniem zawarta teza, że to Bóg nakazuje wszelkie dobre i złe uczynki ${ }^{4}$.

Następnie Saracen zbacza pozornie na kwestię stworzenia świata i człowieka. Jest to sprytny wybieg, ponieważ chrześcijanin, wypowiadając się o stworzeniu świata i człowieka, będzie musiał przyznać, że to jednak Bóg jest odpowiedzialny za ludzkie postępki. Zostaje to przez chrześcijanina zauważone i na pytanie Saracena o to, kto przyczynia się do powstania dziecka w łonie matki, udziela wymijającej odpowiedzi. Chrześcijanin bowiem odwołuje się do znanego z Pisma Starego Testamentu aktu stworzenia świata w ciągu siedmiu dni. Roztacza obraz stworzenia człowieka oraz genealogię ludzkości od Adama. Stara się przez to uzmysłowić, że człowiek tylko raz został stworzony, każde następne pokolenie zaś jest zradzane przez poprzednie. W zradzaniu tym Bóg ma udział, ale jest to udział duchowy. Daje to kontrast do materialnego rozumowana muzułmanów na temat stworzenia człowieka. Według muzułmanów Bóg, tworząc człowieka, od razu przeznacza go do określonej roli. Dyskusja teraz przechodzi na kwestuję chrztu, który według chrześcijan jest najważniejszym kryterium zbawienia. Chrześcijanin udowadnia, że każde pokolenie, począwszy od Adama, przechodziło pewien rodzaj chrztu. Nawet Jezus został ochrzczony przez Jana Chrzciciela, mimo że jest Synem Bożym.

W tym momencie rozmowa ponownie schodzi na kwestię woli Bożej. Według rozumowania Saracena bowiem nawet Chrystus musiał być ochrzczony oraz został ukrzyżowany, ponieważ taka była wola Boga. Chrześcijanin jednak zbywa takie rozumowanie, nazywając to Bożą wyrozumiałością. Ta Boża wyrozumiałość pozostawia wolną wolę człowiekowi. Jednak nawet boska cierpliwość według chrześcijanina ma swe granice, a przykładem przez niego przytoczonym jest klęska i wygnanie żydów oraz zburzenie Świątyni przez Tytusa. To rozumowanie chrześcijanina jest dobrym punktem do przedstawienia doktryny muzułmańskich kadrytów ${ }^{5}$ i ich poglądów na wolę Boga oraz wolną wolę człowieka. Zwolennicy

4 W kontekście posłannictwa prorockiego Mahometa Koran tak mówi o pochodzeniu dobra i zła: Koran IV 79-80.

5 Termin „kadryci” nie określał początkowo żadnego muzułmańskiego ugrupowania. Było to określenie mające charakter wyzwiska, którym określano swoich przeciwników. I tak zwolennicy wolnej woli nazywali kadrytatami deterministów i na odwrót. Żadne ugrupowanie nie odnosiło tego terminu konkretnie do siebie, wszystkie one natomiast brały udział w dyskusji na temat wolnej woli. Mianem kadrytów określa się obecnie ugrupowanie zwolenników wolnej woli, a za ich protoplastę uważa się Ma'bada al.Guhanniego (VIII wiek). Popularny w VIII wieku i w następnych stuleciach ruch został wchłonięty przez nurt mutazylizmu. Por. J. Danecki, Podstawowe wiadomości o islamie, t. 1, Wraszawa 2002, 182-189. 
doktryny negującej wolność człowieka głosili, że Bóg stwarza wszystko w człowieku, dając mu jednak wolę i zdolność do wykonania jakiejś rzeczy. Jednak to Bóg wykonuje tę rzecz za pośrednictwem człowieka. Rezultat tej wykonywanej pracy jest nieznany przez Boga, ponieważ nie ma on wiedzy o przyszłości, dopóki nie przystąpi do pracy, a więc nie jest to predestyna$\mathrm{cja}^{6}$. Na tym gruncie wyrosła doktryna zwolenników wolnej woli. Ruch ten zwany kadrytami rozwijał się od początków VIII do IX wieku. Początkowo zajmował się problematyką polityczną, a mianowicie kwestią postępowania z władcą, który sprzeniewierzył się woli Bożej. Stworzenie koncepcji natychmiastowego usunięcia złego władcy przyczyniło się do wykiełkowania innej myśli dotyczącej grzesznika. Grzesznik nie postępuje zgodnie $\mathrm{z}$ boskimi zaleceniami, zatem grozi mu piekło. Może on jednak się przed nim uchronić, wracając na właściwą drogę postępowania ${ }^{7}$.

Dalsza rozmowa schodzi na tematykę Słowa i Ducha Bożego. Dysputa zaczyna się dotyczyć kwestii, jak rozumieć Słowo Boże. Dla chrześcijanina Słowo jest tożsame z Jezusem. Saracen natomiast pod pojęciem Słowa rozumie Koran (arab. Kalimat Allāh), to on jest jedynym Słowem Bożym objawionym Mahometowi, aby ten przekazał za jego pośrednictwem prawdę ludziom $^{8}$. Powstaje problem relacji Słowo Boże-człowiek. Chrześcijanin, broniąc nauki o wcieleniu Słowa, mówi, że słowo przekazane przez Koran jest tylko metaforą, którą przedstawiał Mahomet tak, aby było zrozumiałe, co z kolei prowadzi do zagadania rozumienia dosłownego i przenośnego Pisma. Dalej następuje wyjaśnienie, że jest to taki zwyczaj proroków, aby podawali w przenośni ostrzeżenia dla ludzi. Następuje wykład o wcieleniu na podstawie zarówno Ewangelii, jak i Koranu. Chrześcijanin musi

6 Doktrynę tę ukuł Abu Muhriza Ğahma, od którego ten kierunek teologii muzułmańskiej nazywano dżahmijja. Doktryna ta stała się celem ataków ortodoksji muzułmańskiej. Por. Danecki, Podstawowe wiadomości, s. 183-184.

7 Na temat koncepcji woli człowieka w ujęciu różnych doktryn muzułmańskich, por. Danecki, Podstawowe wiadomości, s. 182-189.

8 Kwestia rozgraniczenia Słowa Bożego na Słowo Logos i Słowa jako „wersety” Koranu sprawia wrażenie dyskusji trzech osób: ortodoksyjnego chrześcijanina, ortodoksyjnego muzułmanina i muzułmanina o poglądach heretyckich zbliżonego do kadrytów i mutazylitów. Obrazuje to wczesne stadium rozwoju teologii muzułmańskiej. Podobnie jak w przypadku chrześcijaństwa rozwój teologii był odpowiedzią na pojawiające się prądy heretyckie. Fragment dotyczący Słowa Bożego pokazuje nam stan wiedzy Jana z Damaszku na temat islamu we współczesnych mu czasach, w których nie rozróżniano jeszcze Słowa „przedwiecznego” od słów koranicznych jako zapisków. Wczesna teologia islamu nie potrafiła rozgraniczyć, gdzie kończy się „Boskość Słowa” a zaczyna werset je obrazujący. W późniejszej teologii muzułmańskiej Koran jest uznawany za przedwieczny do momentu spisania, spisany zaś uznawany jest jako słowo stworzone. Por. Sahs, John of Damaskus, s. 116-117. 
w toku dysputy wyjaśnić różnicę pomiędzy metaforą a dosłownością, która odsłania również obraz pojmowania zwiastowania Marii. U muzułmanów jawi się ono materialistycznie, podczas gdy pojmowanie chrześcijańskie jest bardziej duchowe. Saracen nie daje za wygraną i docieka, w jaki sposób Jezus, będąc Bogiem, może jeść i pić jak zwykły śmiertelnik. Chrześcijanin przedstawia całą trynitarną doktrynę wypracowaną przez Kościół w toku soborów. W tym miejscu należy wspomnieć o muzułmańskiej szkole jachamickiej, której zwolennicy próbowali kwestię zstapienia Słowa w Marię i jego wcielenia porównać do zstąpienia Słowa Bożego w gorejący krzew. Za takie poglądy byli krytykowani przez ortodoksyjnych sunnitów ${ }^{9}$. Tym można wytłumaczyć dociekanie Saracena na temat wcielenia Słowa Jezusa.

Dyskusja kończy się wymianą poglądów dotyczących chrztu. Saracen, chcąc zmienić niekorzystny dla niego kierunek rozmowy, zadaje trudne pytanie dotyczące otrzymanego przez Jezusa chrztu od Jana Chrzciciela. Kto w tym wypadku jest znaczniejszą osobą: Jezus, Syn Boży, który otrzymuje chrzest, czy Jan Chrzciciel, który tego chrztu udziela? Chrześcijanin odpowiada prostą anegdotką o niewolniku i jego panu. Niewolnik kąpiący i namaszczający swego pana pozostaje tylko sługą nabytym za pieniądze.

\section{Najważniejsze wydania krytyczne}

Obok rozdziału 100/101 De haeresibus wśród pism o islamie przypisywanych Janowi z Damaszku istnieje jeszcze dialog lub też poprawniej rozprawa pomiędzy muzułmaninem a chrześcijaninem. Tekst doczekał się na przestrzeni lat kilku wydań krytycznych. Do najważniejszych należą przekład łacińki R. Grosseteste z 1546, na którym bazuje wydanie łacińskie Michael Lequin (Sancti Patris Nostri Joannis Damasceni Monachi et Presbyteri Hierosolymitani, Opera Omniaqueextant, Parisiis 1712, Apud Johannem Baptistam Delessine). Edycja Lequina zawiera jedynie fragmenty greckie. Grecki tekst całościowo został opublikowany w edycji Gallanda jako S. Joannis Damasceni, Disputatio Saraceni et Christiani

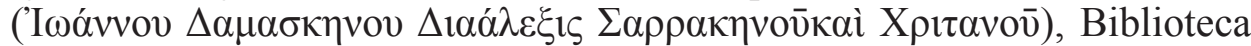
Veterum Patrum XIII, Venise 1779, 272-276. Edycja Migne'a zawiera dwie edycje. Łaciński tekst Lequina wraz z fragmentami, które są zawarte w Opuscula Teodora Abu Qurra ${ }^{10}$ (PG 94, 1585-1598), oraz tekst Gallanda

9 Sahs, John of Damaskus, s. 118.

10 Na ten temat szerzej D.J. Sahas wskazuje na dżahmici (Dżahimijja) i wczesnych mutazylitów. Sahas, John of Damascus on Islam, s. 99-102; Th. Khoury, Les Theologiens 
(PG 96, 1335-1548). Wspomnieć jeszcze należy o edycji B. Kottera (Die Überliefung des Pege Gnoseosdes hl. Johannes von Damaskos, Patristische Texte und Studien 22, Berlin - New York 1963, 427-428) oraz R. Gleia i A. Th. Khoury (Johannes Damascenos und Theodor Abu Qurra. Schriftenzum Islam, Corpus Islamo-Christianum. Series Graeca 3, Würzburg 1995, 168183 - tekst grecki oparty na edycji Kottera wraz z przekładem niemieckim). Obok tych wydań tekstowych istnieje szereg edycji bazujących na tekstach Migne'a, jak w przypadku tekstu dołączonego do monografii D.J. Sahasa (John of Damascus on Islam. The 'Heresy of the Ishmaelites', Leiden 1972 - tekst z przekładem angielskim). Warty odnotowania jest jeszcze przekład angielski Johna W. Voorhisa (The Discussion of a Christian and a Saracen, „The Muslim World” 24 (1935) 391-398). Podstawą do poniższego przekładu jest następujące wydanie krytyczne: R. Le Coz, Jean Damascène, Écrits sur l'Islam, Présentation, Commentaries et Traduction, SCh 383, Cerf, Paris 1992, 209-227.

\section{Transkrypcja arabska}

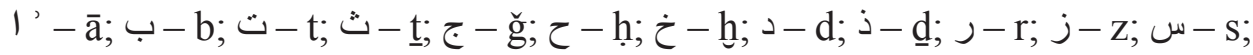

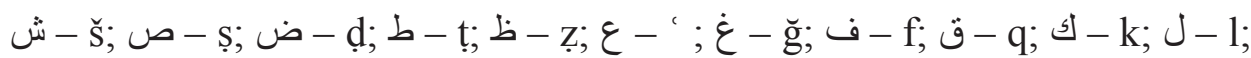

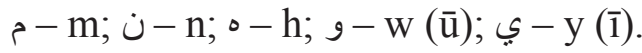

\section{Bibliografia}

\subsection{Teksty źródłowe}

Jan Damasceński, Wykład Wiary Prawdziwej, tł. B. Wojkowski, Warszawa 1969. Bielawski J., Koran, PIW, Warszawa 1986.

Theodorus Abu curacarum episcopus, Opusculum XXXV, PG 97, 1587-1591.

Taqi-ud-Din Al-Hilali M. - Muhammad Muhsin Khan, The Noble Qur'an,in English language, Madinah 2008.

The polemical works of 'Alī al-Tabarī, The history o Christian-Muslim relation, t. 27, red.

R. Ebied - D. Thomas, Leiden - Boston 2016.

Kotter P.B., Die Schriften des Johannes von Damaskos, v. 4, PTS 22, De Gruyter, Berlin 1981.

Byzantins et Islam, Textes et Auteurs (VIII-XIII), t. 1, Louvian 1969. 


\subsection{Opracowania i słowniki}

Kościelniak K., Złe duchy w Biblii i Koranie. Wpływ demonologii biblijnej na koraniczne koncepcje Szatana w kontekście odziaływań religii starożytnych, Kraków 1999, 226261.

Danecki J., Podstawowe wiadomości o islamie, t. 1, Wraszawa 2002.

Gaudefroy-Demombynes M., Narodziny islamu, tł. H. Olędzka, Warszawa 1988.

Lampe G.W.H., A Patristic Greek Lexicon, Oxford 1961.

Jurewicz O., Stownik Grecko-Polski, t. 1-2, Warszawa 2001.

Wehr H., A dictionary of modern written Arabic, New York 1960.

Khoury A.Th., Les Theologiens Byzantins et Islam, Textes et Auteurs (VIII-XIII), t. 1, Louvian 1969.

Badawi E.M., Haleem M.A., Arabic-English dictionary of Qur'anic usage, Brill, Leiden - Boston 2008.

The Dialogue between a Saracen and a Christian, w: Christian-Muslim Relations: A Bibliographical History, red. T.R. Thomas - B. Roggema et alii, t. 1, Laiden - Boston 2009, 295-300.

Haddad R., La Trinité divine chez les théologiesarabes 705-1050, Paryż 1985.

Louth A., St. John Damascene, Tradition and orginality in Byzantine Theology, Oxford 2002.

Maszkowski R., Obraz Jezusa w Koranie i wczesnej tradycji muzutmańskiej, na podstawie literatury niemieckiej, Lublin 2009.

\section{Przeklad ${ }^{11}$}

\section{(1) [Pochodzenie zla]}

Chrześcijanin został zapytany przez Saracena: „Kto, według ciebie, jest przyczyną dobra i zła?”.

Chrześcijanin: [My] mówimy: któż jest przyczyną całego dobra, jeśli nie Bóg, ale [nie jest On przyczyną] zła.

Saracen: (Odpowiada:) kogo [więc] nazwiesz przyczyną zła?

Chrześcijanin: Oczywiście [zło] pochodzi z usposobienia diabła i nas, ludzi.

11 Podstawą przekładu jest wydanie krytyczne: R. Le Coz, Jean Damascène, Écrits sur l'Islam, Présentation, Commentaries et Traduction par Raymund Le Coz, SCh383, Paris 1992, Cerf, 228-251. 
Saracen: Dlaczego tak jest?

Chrześcijanin: Z powodu posiadania wolnej woli ${ }^{12}$.

Saracen: Cóż zatem, jeśli posiadasz wolną wolę ${ }^{13}$, to czy możesz spełnić każde pragnienie i czy czynisz to?

Chrześcijanin: Jedynie [to] drugie, ponieważ zostałem ukształtowany z wolnej woli przez Boga.

Saracen: Jak to?

Chrześcijanin: Czynić zło i czynić dobro to znaczy [czynić rzecz] dobrą i [popełniać] grzech. [W konsekwencji] jeśli czynię zło, podlegam karze [jak wynika z] prawa Bożego, jeśli czynię dobro, nie boję się prawa. Lecz zarówno fakt, że mamy wyznaczoną karę, jak i to, że otrzymujemy zmiłowanie, [pochodzą] od Boga. W ten sam sposób i diabeł przed ludźmi został ukształtowany przez Boga jako posiadający wolną wolę, zgrzeszył i został

12 Zagadnienie to Jan Damasceński omawia w rozdziale XIX ks. IV swojego dzieła Wyktad Wiary Prawdziwej (tł. B. Wojkowski, Warszawa 1969, 245-247). Jan, komentując pochodzenie zła, mówi, że dopuszcza pochodzenie zła: „Właściwe więc jest Pismu Świętemu tak mówić o tym, co Bóg tylko dopuszcza, jak gdyby on sam to sprawiał i jak gdyby Jego dziełem było to, co dopuścił" (Jan Damasceński, Wykład Wiary Prawdziwej, s. 246). Komentuje ten fakt, powołując się na Pismo Święte: „Lecz nawet wtedy, gdy mówi, że «Bóg stworzył zło» (Iz 45,7), albo: «Nie było w mieście takiego zła, którego by Pan nie uczynił» (Am 3,6), nie dla tego tak mówi, że uważa Boga za sprawcę zła, lecz dlatego, że w Piśmie świętym wyraz ,zło” nie jest jednoznaczny, bo występuje w dwu znaczeniach

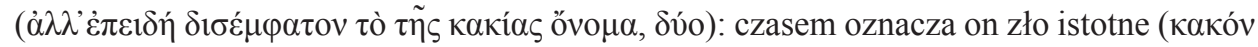

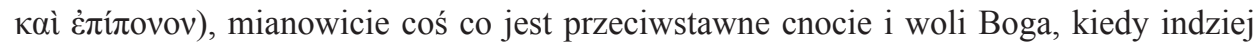
zaś coś, co jest złe i przykre w naszym odczuciu, jak cierpienia i klęski. Są one z pozoru czymś złym, gdyż dotkliwie je odczuwamy, w rzeczywistości stanowią dla nas prawdziwe dobro, gdyż przyczyniają się u ludzi myślących do opamiętania i pomagają do zbawienia. Takiego rodzaju zło jest według Pisma Świętego dziełem Boga” (Jan Damasceński, Wyktad Wiary Prawdziwej, s. 246). Dalej autor wspomina jeszcze o fakcie pochodzenia zła wynikającym z działania człowieka: „Trzeba jednak pamiętać o tym, że raczej my sami jesteśmy też sprawcami i takiego zła. Bo takie zło nie chciane wypływa ze zła, którego chcieliśmy" (Jan Damasceński, Wykład Wiary Prawdziwej, s. 247). Muzułmańscy zwolennicy doktryny kadarytów również stawiali sobie pytanie na temat pochodzenia zła wynikającego z wolnej woli człowieka. Al-Ḥasan z Basry (zm. 728) twierdził, że Bóg z góry wyznaczył czas śmierci człowieka, posiadany majątek, jego nieszczęścia i dobre uczynki. A jeśli chodzi o grzech, to za jego popełnianie odpowiedzialny jest sam człowiek, ewentualnie Szatan. Wynika z tego, że Bóg stworzył jedynie dobro, zło zaś jest wynikiem działalności człowieka lub Szatana. Sam człowiek ma wolny wybór pomiędzy dobrem a złem, a Bóg wie, co człowiek wybierze i jak postąpi. Na temat kadaru, patrz: J. Danecki, Podstawowe wiadomości o islamie, t. 1, Wraszawa 2002, 184-189.

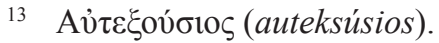


przez Boga pozbawiony właściwego jemu stanu ${ }^{14}$. Lecz ty prawdopodobnie szybko prześledzisz [ten] temat, sprzeciwiając się $\mathrm{mi}^{15}$ [i powiesz]: „,co jest tym, co nazywasz dobrą [rzecza], a co grzechem? Patrz, oto słońce, księżyc i gwiazdy są [rzeczami] dobrymi. Takimi zostały uczynione!”. W tym sensie nie rozmawiałem z tobą wcześniej; [nie] odnosiłem się do ludzi czyniących dobro i zło. Jakiekolwiek dobro jest uwielbieniem Boga i modlitwą, i miłosierdziem, i temu podobnymi; zło zaś - cudzołóstwem, kradzieżą i temu podobnymi.

\section{(1.1) [Boża sprawiedliwość]}

Skoro jeśli ty w ten sposób twierdzisz, że dobro i zło pochodzą od Boga, to Bóg okazuje się według ciebie być niesprawiedliwy. Nie jest [to prawdą]. Od kiedy bowiem Bóg polecił cudzołożnikowi cudzołożyć, złodziejowi kraść, zabójcy mordować? Jeśli byłoby tak, jak ty twierdzisz, ludzie

14 Na temat pochodzenia Szatana Jan Chryzostom w Wykładzie Wiary Prawdziwej mówi tak: „Jeden spośród aniołów stał na czele owych zastępów, którym została powierzona strefa dookoła ziemi, i na zlecenie Boga sprawował nadzór nad ziemią. Nie jest prawdą, że był on zły z natury, przeciwnie, Bóg stworzył go dobrym i dla dobra, tak że nawet cienia zła nie miał on w sobie od Stwórcy. Nie zdołał jednak znieść tego światła [...], podniósł się na stwórcę swego, Boga, by mu wypowiedzieć posłuszeństwo. I tak pierwszy [ze stworzeń] odpadł od Boga i stał się złym. [...] Choć więc stworzył go Bóg, jako światło i dobro [...] on z własnej woli stał się ciemnością" (Jan Damasceński, Wykład Wiary Prawdziwej, s. 68).

15 Koran w surze II, 34 ujmuje bunt, upadek Szatana - Iblīsa (إِبِِليس / 'iblīs) w następujący sposób: „A kiedy powiedzieliśmy do aniołów: «Oddajecie pokłon Adamowi!», oni oddali pokłon z wyjątkiem Iblīsa. On odmówił, wbił się w pychę (أَََى وَاسْنَكْبَرَ) wa-is 'stakbara) i znalazł się wśród niewiernych". Przekład Koranu na język polski za: J. Bielawski, Koran, Warszawa 1986, PIW. Tekst arabski: M. Taqi-ud-Din Al-Hilali, Muhammad Muhsin Khan, The Noble Qur'an, in English language, Madinah 2008. „Teologia” muzułmańska zakłada kompromis pomiędzy możliwością a niemożliwością buntu aniołów przeciw rozkazom Boga. Hadīty przekazują natomiast różnice pomiędzy aniołami a dżinami. Iblīs, nie będąc aniołem tylko dżinem, miał wślizgnąć się do raju pomiędzy aniołów, gdzie nie wytrzymał próby, jaką postawił przed nim Bóg, aby wyeliminować jego arogancję i uzurpację. Nauka muzułmańska jest niekonsekwentna w odniesieniu do Iblīsa i pochodzenia zła. Jednak to jego można utożsamić ze złem osobowym sprowadzającym człowieka ku złym wyborom. Szczegółowo ten temat w: K. Kościelniak, Złe duchy w Biblii i Koranie. Wptyw demonologii biblijnej na koraniczne koncepcje Szatana w kontekście odziaływań religii starożytnych, Kraków 1999, 226-261. 
ci zasługiwaliby na szacunek za okazywanie posłuszeństwa woli Bożej ${ }^{16}$.

16 W Koranie niektóre istoty i niektórzy ludzie mają z góry wyznaczony los przez Boga (sura VII, 178-179): „A kogo prowadzi Bóg drogą prostą, ten idzie drogą prostą; a kogo on sprowadzi z drogi, to tacy są straceni. Stworzyliśmy dla Gehenny wielu spośród dżinów i ludzi: Oni mają serca, którymi nie pojmują; oni mają oczy, którymi nie widzą; oni mają uszy, którymi nie słyszą! Oni są podobni do bydła, a nawet jeszcze bardziej zabłąkani! Tacy są całkowicie beztroscy!". Werset nr 179 jest uważany za wystarczający dowód na obronę twierdzenia o przeznaczeniu niektórych ludzi do raju lub piekła. Szerzej w: M. Gaudefroy-Demombynes, Narodziny islamu, tł. H. Olędzka, Warszawa 1988, 259263. Kadaryci głosili ideę, że nie jest prawdą, jakoby Bóg określał z góry, co dzieje się w życiu człowieka (tzw. indeterminizm). Bóg nie określa odgórnie ludzkich działań, jedynie podaje zalecenia, nie przekreślając z góry losu grzesznika. W rozumieniu kadarytów grzesznik winien być traktowany jako hipokryta, któremu groziło piekło. Jednak może się on od niego uchronić, jeśli będzie postępował zgodnie z boskimi zaleceniami. Por. J. Danecki, Podstawowe wiadomości o islamie, t. 1, s. 188. Doktryna kadarytów jest przeciwstawna innemu muzułmańskiemu nurtowi - dżahimijja, który negował wszelką wolność wyboru (wolną wolę) człowieka. Zdaniem twórcy tego kierunku myślenia, Abū Muhriza Ğahma Ibn Șafwāna, Bóg stwarza wszystko, co istnieje na świecie. Dotyczy to również wszystkiego, co człowiek czyni. Człowiekowi wydaje się jedynie, że coś czyni, a w rzeczywistości wszystko pochodzi od Boga. Por. J. Danecki, Podstawowe wiadomości o islamie, t. 1, s. 183-184. Wykład Wiary Prawdziwej wydaje się najlepszym punktem odniesienia do treści odpowiedzi udzielanej przez chrześcijanina. Jan Damasceński stawia tezę: „W sprawie wolnej woli, czyli samostanowienia, nasuwa się pytanie, czy w ogóle możemy w czymkolwiek stanowić sami o sobie, [...]" (Jan Damasceński, Wykład Wiary Prawdziwej, s. 115). Jan podejmuje się tu odparcia twierdzeń gnostyków i manichejczyków odnośnie do determinizmu, wykorzystując następnie zebrane doświadczenie w polemice $z$ islamem. Przedstawia a następnie zbija argumenty przyczynowe postepowania człowieka: „Przyczyną sprawczą wszystkiego, co się staje, jest - twierdzą - Bóg, albo konieczność (ananke), albo przeznaczenie (heimarmene), albo natura, albo los (tyche), albo przypadek" (Jan Damasceński, Wykład Wiary Prawdziwej, s. 116). Podsumowuje to stwierdzeniem, że człowiek używa rozumu (namysłu) jako przedmiot swego działania. Jan definiuje wolną wolę i podejmowane przez człowieka uczynki (ks. II, rodz. XXVI, 117-118) jako częściowo zależne, a częściowo niezależne od człowieka. Wyboru dokonuje rozum i on jest zasadą wolnego działania. Z wolnej woli wynika możliwość poruszania się lub nieporuszania się, dokonywania lub niedokonywania napadu albo wybór zawodu (sztuki), jaki chcemy wykonywać. Jednocześnie rozważania te podsumowuje tak: „Należy jednak zauważyć, że jakkolwiek zawsze możemy uczynić wybór jakiegokolwiek działania, to przecież często wykonanie go uniemożliwi w jakiś sposób Boska Opatrzność

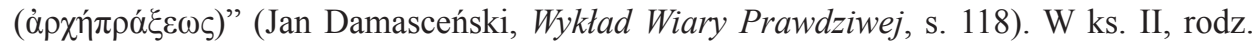
XXVII rozwija to zagadnienie głębiej. W rozdziale XXX Jan wyjaśnia, że Bóg zna konsekwencje ludzkich wyborów, jednak nie ustala niczego z góry: „Najpierw trzeba przyznać, że chociaż Bóg wie naprzód wszystko, to jednak nie wszystko z góry ustala. Wie naprzód, jakie będą nasze wolne czyny, ale ich przez to nie ustala. Nie chce, by działo się zło, ale 
W ten sposób okaże się, że twoi prawodawcy [są] kłamcami, twoje pisma [są fałszywe, ponieważ polecają oni obdzierać ze skóry cudzołożnika ${ }^{17}$ i złodzieja ${ }^{18}$ za to, że okazują posłuszeństwo Bogu i [nakazują] zabić ${ }^{19}$ mordercę $^{20}$, którego należałoby szanować za to, że spełnił wolę Boga.

\section{(1.2) [Kreacja a prokreacja]}

Saracen: Kto zatem - mówi [dalej] - kształtuje dzieci w macicach kobiet? Saracenii wysuwają ten [zarzut], ponieważ chcą pod [pozorem tej] kwestii dowieść, że Bóg jest sprawcą zła. Jeśli bowiem odpowiesz, że Bóg kształtuje dzieci w macicach kobiet, Saracen oznajmi: „Oto Bóg jest tym, który współpracuje w rozwiązłości i cudzołóstwie!’”21.

przecież nie zmusza nas siłą do cnoty. Cokolwiek zatem ustala z góry, czyni to w oparciu o swoją boską wiedzę, wyprzedzającą zdarzenia" (Jan Damasceński, Wykład Wiary Prawdziwej, s. 124).

17 Do cudzołóstwa Koran odnosi się np. w surze XXIV, 2-10: „Cudzołożnicy i cudzołożnikowi wymierzcie po sto batów, każdemu z nich obojga! W imię religii Boga, jeśli wierzycie w Boga i w Dzień Ostatni, niech nie powstrzyma was żadna względem nich pobłażliwość. I niech pewna grupa wiernych będzie obecna przy ich karze. Cudzołożnik pojmie za żonę tylko cudzołożnicę lub bałwochwalczynię; a cudzołożnicę może pojąć za żonę tylko cudzołożnik lub bałwochwalca. To wszystko jest zabronione tym, którzy wierzą. A tym, którzy oskarżają kobiety godne, a nie mogą przyprowadzić czterech świadków, wymierzcie osiemdziesiąt batów i nie przyjmujcie od nich nigdy świadectwa. To są ludzie szerzący zgorszenie [...]".

18 Sura V, 38: „Złodziejowi i złodziejce obcinajcie ręce w zapłatę za to, co oni popełnili. To jest przykładna kara od Boga. Bóg jest potężny, mądry!”.

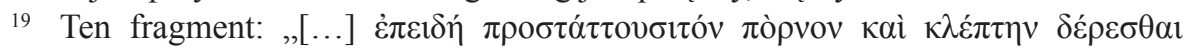

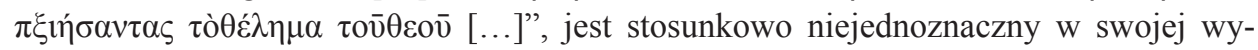
mowie z powodu użytego terminu $\delta \varepsilon ́ \rho \varepsilon \sigma \theta \alpha 1 / \delta \varepsilon ́ \rho \omega$ ('odzierać ze skory, ściagać skórę, dać w skórę, zbić, oćwiczyć, uderzyć’). W słowniku Lampe posiada jeszcze znaczenie 'wiązać, zgiąć, skrępować ręce'. G.W.H. Lampe, A Patristic Greek Lexicon, Oxford 1961

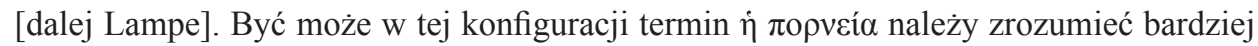
radykalnie.

20 Odnośnie do morderstwa Koran odwołuje się do prawa talionu: sury II, 178-179; II, 194; IV, 92; V, 45; XVI, 126; XVII, 33; XXII, 60.

21 Ta część dialogu ma swój odpowiednik w: Teodor Abu Qurra, Opusculum 35, PG 97, 1587-1591. W Koranie (sura LXXX, 17-22) znajduje się fragment, który może łączyć akt stworzenia ze sprawiedliwością Bożą i przeznaczeniem człowieka: „Niech zginie człowiek! Jakże on jest niewdzięczny! Z czego On go stworzył? On go stworzył z kropli

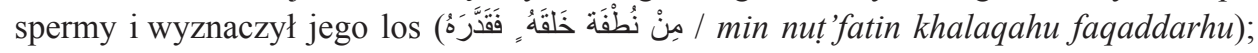


Chrześcijanin (względem tego [pytania] odpowiada:) W żaden sposób nie znajdujemy potwierdzenia w Piśmie Świętym, że Bóg kształtuje albo tworzy coś po pierwszych siedmiu dniach [istnienia] świata. Jeśli masz wątpliwości na ten temat, to pokaż jakąkolwiek istotę stworzoną albo ukształtowaną po pierwszych siedmiu dniach [istnienia] świata, lecz żadnej nie jesteś w stanie wskazać, wszystko bowiem widzialne zostało stworzone w pierwszych siedmiu dniach ${ }^{22}$. Bóg bowiem ukształtował człowieka w pierwszych siedmiu dniach i rozkazał mu, aby był płodny i rozmnażał się, mówiąc: „Rozwijajcie się i mnóżcie, i napełniajcie ziemię"23. Ponieważ człowiek był istotą żywą ${ }^{24}$ posiadającą nasienie $^{25}$, [które] zasiane, wzrastało [dalej] w jego własnej żonie. A zatem człowiek rodzi człowieka, jak mówi pismo Boże: „Adam bowiem zrodził Seta, Set zrodził Enosza, Enosz zrodził Kenana, Kenan zrodził Mahalaeela, Mahalaeel zrodził Jereda, Jered zrodził Henoha"26. I nie mówi: Bóg ukształtował Seta albo Enosza, albo któregoś innego. Stąd wiemy, że Adam był jedynym ukształtowanym przez Boga, pozostali zaś zostali spłodzeni, a następnie rodzą się aż do dzisiaj. I w ten sposób dzięki łasce Bożej świat jest ustalony, skoro i każde ziele, i roślina na rozkaz Boga rodzi się i jest zradzane [aż do dzisiaj]. Bóg bowiem mówi: „Niech ziemia wyda ziele pastwisk”27. Na Jego rozkaz wyrosło każde drzewo i wszystkie gatunki roślin i ziół, [które] mają w sobie zdolność ${ }^{28}$ [wzrastania] z nasion. Nasienie każdej rośliny i zioła jest

następnie uczynił jego drogę łatwą. Potem On sprowadza jego śmierć i każe go pochować w grobie. Potem On wskrzesi go kiedy zechce".

22 Koran, opowiadając o akcie stworzenia człowieka, wskazuje również, że nie tylko Adam został bezpośrednio stworzony przez Boga, który ingeruje również w akt stwórczy potomstwa Adama (sura XXXII, 7-8): „On jest Tym, który doskonale stworzył

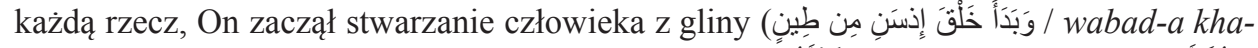

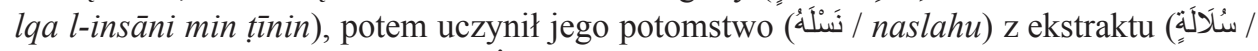

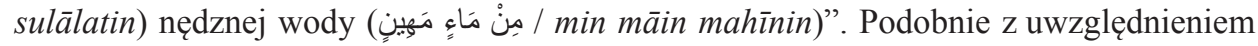
etapu zarodkowego ciąży mówi sura XXIII, 12-14: „Stworzyliśmy człowieka z ekstraktu gliny. Następnie umieściliśmy go - jako kroplę nasienia (نُطْفَف / nut’fatan) - w naczyniu solidnym. Następnie stworzyliśmy z nasienia grudkę krwi zakrzepłej zalążek ciała; a z tego zalążka stworzyliśmy kości; wtedy oblekliśmy te kości ciałem; następnie uczyniliśmy go innym stworzeniem. Niech będzie błogosławiony Bóg, najlepszy ze stwórców”.

$23 \mathrm{Rdz} 1,28$.

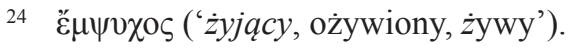

25 Tó $\sigma \pi \varepsilon ́ p \mu \alpha$ (nasienie, zarodek, zalążek, zarzewie, sperma').

26 Rdz 5,3-20. Por. również: Teodor Abu Qurra, Opusculum 35, PG 97, 1591.

$27 \mathrm{Rdz} 1,11$.

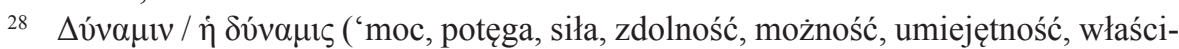
wość, cud'). O. Jurewicz, Stownik Grecko-Polski, t. 1-2, Warszawa 2001 [dalej Jurewicz]. 
[bowiem] żywe. Każde z nich, upadłszy na ziemię lub zostawszy zasianym, wzrasta. Nie jest kształtowane przez kogoś, lecz jest posłuszne pierwotnemu nakazowi Boga. Oto i ja, jak powiedziałem wcześniej, posiadając wolną wolę, w tej jedynej dziedzinie, o której mówiłem, jeśli złożę moje nasienie we własnej żonie albo jakiejś innej [kobiecie], przestrzegając pierwotnego porządku Boga, to będzie ono wzrastało. Nie dlatego, że i teraz znowu każdego dnia [Bóg] kształtuje i dokonuje dzieło [stworzenia], skoro w pierwszych siedmiu dniach „Bóg uczynił niebo i ziemię, i cały świat i siódmego dnia odpoczął od wszystkich zajęć, które uczynił swoim działaniem"29.

\section{(1.3) [Zrodzenie Syna przez Ojca]}

Saracen: I dlaczego Bóg mówi do Jeremiasza: „Zanim ukształtowałem cię w łonie matki, znałem cię i uświęciłem cię?"30.

Chrześcijanin: Począwszy od Adama, którego potomków Bóg obdarował mocą przekazywania życia poprzez zapłodnienie, kształtuje każdego człowieka w łonie jako istotę żyjącą. Adam bowiem mający w [swoim] łonie Seta, zrodził go zgodnie z przepowiednią; Set [zrodził] Enosza i [w ten sposób] każdy człowiek mający pierwej we własnym łonie swego syna rodzi go i tak rodzą się kolejni potomkowie aż do naszych czasów. [Słowa]: „od łona uświęciłem cię" zrozum [w tym znaczeniu], że łono w rzeczywistości rodzi Boże dzieci, według świadectwa świętej Ewangelii: „Wszyscy, którzy $\mathrm{Je}^{31}$ przyjęli - powiada - wszystkim, którzy wierzą w Jego imię, dało moc, aby stali się dziećmi Bożymi”. [Dalej Ewangelia] mówi: „ci nie zrodzili się ani z krwi, ani z woli człowieka, ani z woli ciała, lecz z Boga"32, to znaczy przez chrzest.

\section{(2) [Chrzest i zbawienie]}

Oponent ${ }^{33}$ : Ale czy był chrzest przed Chrystusem? Jeremiasz bowiem narodził się przed Chrystusem.

\footnotetext{
$29 \operatorname{Rdz} 2,1-3$.

30 Jr 1,5 .

31 Chodzi o Słowo Boże - Logos.

32 J 1,12-13.

33 W tym miejscu występuje zmiana rozmówcy. W tekście greckim oznaczone jest

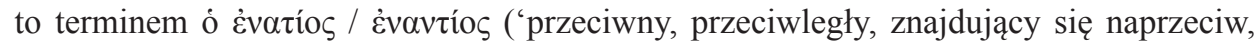
stojący naprzeciw w boju, przeszkadzający’). Zob. Jurewicz.
} 
Chrześcijanin: Według świadectwa świętego Apostoła, [który] mówi o tym, było tak: „Jedni ochrzczeni byli w obłoku, drudzy w morzu" 34 . I Pan w Ewangeliach mówi: „Jeśli ktoś nie narodził się z wody i Ducha, nie wejdzie do Królestwa Niebieskiego"35. Również Abraham, Izaak, Jakub i pozostali święci poprzedzający Chrystusa, którzy weszli do Królestwa Niebieskiego, ochrzcili się wcześniej, jeśli by się nie ochrzcili, nie doznaliby zbawienia. Zaświadcza o tym Duch Święty, kiedy mówi: „Od łona występni oddzielili się"36, to znaczy chrztu. Dlatego wyznajemy, że wszyscy zbawieni zostali ocaleni przez chrzest i zbawieni łaską Boga ${ }^{37}$.

\section{(3) [Wola i tolerancja]}

Saracen: Powiedz mi, ten, kto czyni wolę ${ }^{38}$ Boga, jest dobry czy zły?

Chrześcijanin (poznawszy jego podstęp, odpowiada:) Wiem, co chcesz powiedzieć.

Saracen: Wyjaśnij mi to!

Chrześcijanin: Chcesz mnie zapytać, czy Chrystus chciał cierpieć czy też nie? ${ }^{39}$ Jeśli odpowiem tobie: „Chciał cierpieć”, abyś ty mógł powiedzieć: „Dalej, idźcie, pokłońcie się Żydom, ponieważ oni wykonali wolę Boga”.

Saracen: To właśnie jest to, co chciałem ci powiedzieć. Jeśli możesz mi na to odpowiedzieć, zrób to!

Chrześcijanin: To, co ty nazywasz „wolą”, ja nazywam ,pobłażliwością” i ,wielkodusznością".

Saracen: Jak możesz to udowodnić?

Chrześcijanin: Rozpocznę od odwołania się do prostych czynności. Otóż kiedy siedzimy albo stoimy, [to czy] jeden z nas może się podnieść albo poruszyć bez woli i władzy Boga?

Saracen: Nie.

\footnotetext{
341 Kor 10,2 .

$35 \mathrm{~J} 3,5$.

36 Ps 58,4.
}

37 Odnośnie do „chrztu” przed Chrystusem, zob. Jan Damasceński, Wykład Wiary Prawdziwej, s. 206: „Już na początku bowiem «Duch Boży unosił się nad wodami» (Rdz 1,2) i od początku, jak poświadcza Pismo, woda miała moc oczyszczania (Kpł 15,10). Przez wodę zmył Bóg za czasów Noego grzech świata (Rdz 6,13.17). Przez wodę oczyszczał się każdy nieczysty w myśl nakazu Prawa [...]”.

38 Tó $\theta \varepsilon ́ \lambda \eta \mu \alpha$ ('wola, pragnienie, upodobanie'). Zob. Jurewicz.

39 Jan wyjaśnia to zagadnienie w kontekście modlitwy Jezusa w Ogrójcu w: Jan Damasceński, Wykład Wiary Prawdziwej, s. 189-190. 
Chrześcijanin: Skoro Bóg powiedział: „Nie kradnij! Nie cudzołóż! Nie morduj!”, to czy chce, abyśmy kradli, dopuszczali się cudzołóstwa i mordowali?

Saracen: Nie. Jeśli bowiem chciałby [abyśmy to robili], nie powiedziałby: „Nie kradnij! Nie cudzołóż! Nie morduj!”.

Chrześcijanin: Chwała niech będzie Bogu, zgadzasz się z tym, co powiedziałem. Oto zgodziłeś się ze mną, że nikt z nas bez Boga nie może stanąć lub poruszać się i że Bóg nie chce, abyśmy kradli lub cudzołożyli. Jeśli [teraz] powstawszy, dopuszczę się kradzieży albo cudzołóstwa, stosownie [do tego] wstałem i ukradłem [coś] albo cudzołożyłem, co z tego nazwiesz „wolą” Boga albo „zgodą”, albo „cierpliwością”, albo „wielkodusznością"? ${ }^{40}$

Saracen, zrozumiawszy to wszystko, wyraził swój podziw, mówiąc: Doprawdy, tak jest.

Chrześcijanin: Pomyśl i o tym, że chociaż Bóg mógł uderzyć [swoich wrogów], zaniechał tego, to znaczy był wielkoduszny względem grzechu. Lecz jeśli zechce, abym żałował [za grzech], zapłaci mi w ten sam sposób, jak uczynił to Żydom. Jakiś czas po tym, wzbudził przeciwko nim Tytusa i Wespazjana oraz Greków i rozproszył ich arogancję.

\section{(4) [Chrystus Bogiem]}

Jeśli Saracen zapyta cię, „kim jest Chrystus”41. Odpowiedz mu: „Słowem Boga". Pismo Swięte nie zwodzi nikogo, skoro nazywa [Chrystusa] „Słowem”42 i „Mądrością"43, i „Ramieniem”"44, i „Mocą" ${ }^{45}$, i innymi tego

40 Rozwinięcie tej myśli: „Zatem ów tekst na wstępie - jak i ten: «Zatwardził Bóg wszystkich w nieposłuszeństwie» (Rz 11,32) i «Dał im Bóg ducha zamroczenia, oczy nie widzące, i uszy nie słyszące» (Rz 11,8; Iz 6,10; 29,10) należy rozumieć nie o Bożym działaniu sprawczym, lecz jedynie o dopuszczeniu Bożym, zakładając naszą wolną wolę.

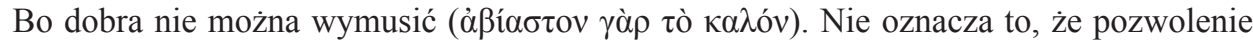
implikuje współudział Boga w złych uczynkach człowieka, nawet jeśli je wypacza" (Jan Damasceński, Wykład Wiary Prawdziwej, s. 246). Por. J. Damascène, Écrits, s. 157-158.

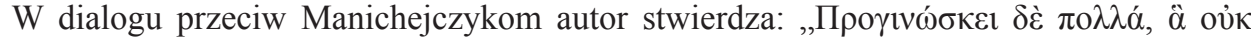

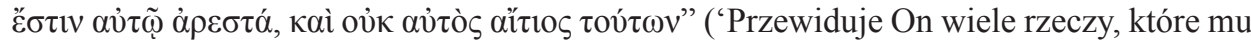
się nie podobają, ale nie jest On tym, który je powoduje'). P.B. Kotter, Die Schriften des Johannes von Damaskos, vol. 4, PTS 22, Berlin 1981, De Gruyter, 394.

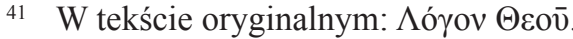

42 ó $\lambda$ ó $о$ os.

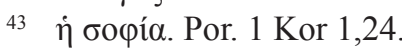

$44 \dot{\eta} \beta \rho \alpha \chi i ́ \omega v$. Por. Łk 1,51.

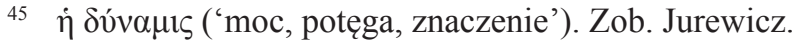


typu [imionami], ponieważ [Chrystus] ma wiele imion. Ty z kolei zwróć się do niego z następującym pytaniem: „Jak nazywany jest Chrystus w twoim Piśmie?". A jeśli będzie próbował wykręcić się od odpowiedzi, stawiając inne pytanie, nie odpowiadaj mu, dopóki wpierw nie odpowie na twoje. W ten sposób zmusisz go do następującej odpowiedzi: „Zgodnie z moim Pismem, Chrystus jest nazywany Duchem i Słowem Boga"46. I jeśli ci odpowie w ten sposób, [zapytaj] ponownie: „Czy według twojego Pisma Duch Boży i Słowo są niestworzone czy też stworzone?”. A jeśli ci odpowie, że niestworzone, powiedz mu: „Tak samo mówi moje Pismo”, są bowiem niestworzone przez nikogo, lecz Bóg je wydał ${ }^{47}$. Jeśli zaś z całkowitym przekonaniem odpowie, że są stworzone, powiedz mu: „Zatem kto stworzył Ducha i Słowo Boga?”. I jeśli z zaniepokojenia powie, że sam Bóg je stworzył, odpowiedz mu: „Przed chwilą powiedziałaś, że są niestworzone, a teraz mówisz, że Bóg je stworzył. Jeśli więc powiedziałem ci to samo, co i ty mi powiedziałeś, to sprzeniewierzyłeś się swojemu świadectwu, stąd cokolwiek [powiesz], już ci nie uwierzę. Mimo wszystko pytam się raz jeszcze: Czy przed stworzeniem Ducha i Słowa Bóg był bez Ducha i Słowa?". I ucieknie od ciebie, nie mając ci nic do powiedzenia. Ci bowiem, którzy mówią takie rzeczy, są przez Saracenów uważani za heretyków i są odrzucani, i znienawidzeni. A jeśli zechcesz wydać go pozostałym Saracenom, będzie się ciebie bał ${ }^{48}$.

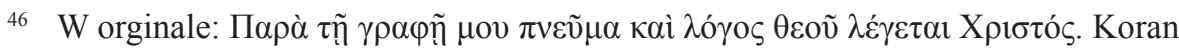
nazywa Jezusa Słowem Boga. W surze III, 45: „Oto powiedzieli aniołowie: «O Mario! Bóg zwiastuje ci radosną wieść o Słowie (بكَلِّمَ / bi-kalomatin) pochodzącym od Niego,

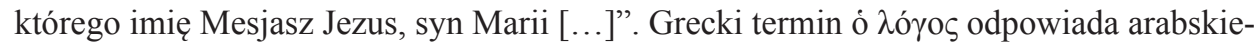
mu كلمة (kalima), który oznacza 'słowo, przemówienie, wypowiedź, uwagę, znaczenie, świadectwo, powagę, autorytet'. H. Wehr, A dictionary of modern written Arabic, Nowy York 1960. Odnośnie do określeń Jezusa jako Słowa i Ducha Boga to w surze IV, 171 czył

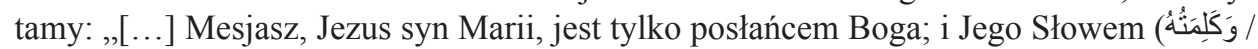
wa-kalimatuhu), które złożył Marii; i Duchem (وَرُوُحُ / wa-rūhun) pochodzącym od Niego [...]". Grecki termin $\pi v \varepsilon \bar{v} \mu \alpha$, który wskazuje Jan, jest odpowiednikiem arabskiego terminu رُو tradycji muzułmańskiej, na podstawie literatury niemieckiej, Lublin 2009, 142-146.

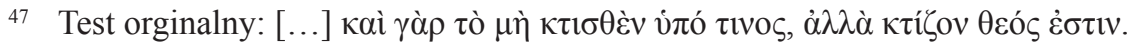

48 Ten fragment wydaje się być aluzją do jakieś „,heretyckiej” grupy w łonie islamu. D.J. Sahas wskazuje na dżahmitów (Dżahimijja) i wczesnych mutazylitów. D.J. Sahas, John of Damascus on Islam, the „Heresy of the Ishmaelites”, Leiden 1972, Brill, 114. Dżahmici głosili, że Bóg jest niepoznawalny i jako absolut jest przeciwieństwem człowieka. Twierdząc, że Bóg nie posiada żadnych cech, odrzucali tym samym wszystkie atrybuty Boga. Takie twierdzenie stało się celem ataków ze strony ortodoksyjnych muzułmanów. Szerzej w: J. Danecki, Podstawowe wiadomości o islamie, t. 1, s. 183-186. 


\section{(5) [Słowa a komunikacja]}

A jeśli Saracen zada tobie pytanie: „Czy słowa (Lógia) ${ }^{49}$ Boga są stworzone czy niestworzone?", [Saracenii] zadając nam [chrześcijanom] to pytanie, chca dowieść, że „Słowo ${ }^{50}$ (Lógos)” Boga jest stworzone, co nie jest prawdą. Jeśli zaś powiesz, że nie jest stworzone, on ci odpowie, że w ten sam sposób mówisz o stworzonym „Słowie ${ }^{51}$ (Lógos)” Boga. Jeśli zaś odpowiesz, niestworzone, odpowie, że w ten sam sposób wszystkie istniejące ,słowa (Lógia) ${ }^{52}$ ", Boga są niestworzone, jednak nie są bogami. Zgadzasz się zatem ze mną, że Chrystus, który jest „Słowem” Boga, nie jest Bogiem. Dlatego nie odpowiadasz ani stworzony, ani niestworzony, ale odpowiadasz mu w ten sposób: ,Ja wyznaję jednego Boga, który jest «Słowem» w jednej «hipostazie» ${ }^{53} \mathrm{i}$ jest niestworzony, jak również ty to przyznałeś. [Dlatego też] nie nazywam mojego Pisma „Słowem (Lógos)" lecz ,językiem komunikacji ${ }^{54}$ (rhēma)" ${ }^{\text {55 }}$.

Jeśli Saracen powie: „Dlaczego Dawid powiedział: «Słowa (Lógia) Pana [są] słowami (Lógia) świętymi», a nie «język komunikacji (rhēma) jest święty?»", powiedz mu, że prorok mówił to w sensie alegorycznym ${ }^{56}$, a nie w sensie literalnym ${ }^{57}$.

49 Tó $\lambda$ ó $10 v$ ('wypowiedź, powiedzenie'). Zob. Lampe.

50 ò $\lambda$ ó $\gamma$ os.

51 ò $\lambda$ ó $о$ os.

$52 \lambda{ }^{2} \gamma 1 \alpha$.

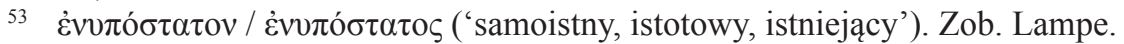

54 Termin $\tau$ ó $\rho \tilde{\eta} \mu \alpha$ jest bardzo trudny do oddania w języku polskim w takim znaczeniu, w jakim używa go Jan z Damaszku. Słownik Jurewicza podaje następujące znaczenia: 'słowo, wyraz, powiedzenie, język, rozmowa, wiersz, linia, temat rozmowy, wydarzenie, czasownik'. Słownik Lampe'go posiada bardziej adekwatne znaczenie opisowe, jakim jest: 'to, co zostało powiedziane, wypowiedziane'.

55 Rozróżnienie i podział w terminologii na $\lambda o ́ \gamma 1 \alpha$ i $\rho \tilde{\eta} \mu \alpha$ świadczy o zadawaniu sobie, w czasach Jana z Damaszku, przez muzułmanów pytania o wieczność Słowa Bożego (Koranu) w kontekście chrześcijańskiej doktryny o odwiecznym Słowie Boga (Chrystusie), której wpływ nie jest do końca jasny. Muzułmanie zaczęli zadawać sobie pytanie, czy jeśli Bóg posiada rozum, to logiczne wydawało się stwierdzenie, że posiada również słowo (mowę). Słowo Boga zatem jest wieczne, a jest nim Koran. W Koranie Chrystus jest zarówno Słowem Bożym, jak i stworzonym przez Słowo Boże, ale z pełną stanowczością zaprzeczone jest określenie, że Chrystus jest Synem Boga. Z tego powodu nie może być uznawany za prawdziwe Słowo Boga, jakim jest Koran. Por. A.Th. Khoury, Les Theologiens Byzantins et Islam, Textes et Auteurs (VIII-XIII s.), t. 1, Louvian 1969, 78, przyp. 25.

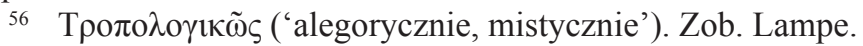

57 Kvpıло $ү 1 \kappa \tilde{\omega} \varsigma$ ('przez dosłowne użycie słowa'). Zob. Lampe. Zagadnienie dosłownego i przenośnego mówienia o Bogu Jan Damasceński wyjaśnia następująco: 


\section{(6) [Wcielenie]}

Jeśli Saracen zapyta cię: „W jaki sposób Bóg zstąpił do łona kobiety?”, odpowiedz: „Wykorzystajmy twoje i moje Pismo! W twoim Piśmie czytamy, że Bóg oczyścił zawczasu ${ }^{58}$ z wszelkiej kobiecej cielesności, zstąpił do niej Duch i Słowo Boga; i moja Ewangelia mówi: «Duch Święty zstąpi na ciebie i moc Najwyższego okryje cię ${ }^{59} 》$. Widzisz, jedno i drugie [Pismo] ma to samo słownictwo i to samo znaczenie. Wiedz i to, że jest to osobliwe znaczenie słów naszych Pism o zstąpieniu i wejściu Boga na sposób alegoryczny, a nie dosłowny. W sensie dosłownym bowiem zstąpił i wstąpił w odniesieniu do ciała, zgodnie z tym, co naucza filozofia, podczas gdy Bóg obejmuje wszystko, a sam nie jest niczym objęty. Jeden z proroków mówi tak: «Któż zmierzy swą dłonią wodę morską i niebo razem $\mathrm{z}$ jego rozpiętością i całą ziemię obejmie $\mathrm{w}$ dłoni? ${ }^{60}$. [To znaczy -] wszystkie wody są w ręku Boga, całe niebo wraz z jego rozpiętością i cała ziemia $w$ jego dłoni. W jaki sposób można przyjąć do siebie tego, który własną ręką trzyma wszystko, co się wznosi i zstępuje?".

\section{(7) [Unia hipostatyczna]}

A gdy zapyta ciebie Saracen: „Jeśli Chrystus jest Bogiem, to jakże to było możliwe, że jadł, pił, spał i [czynił te] pozostałe rzeczy?", powiedz

\footnotetext{
„W Piśmie Świętym często napotykamy zwroty, w których symbolicznie przypisywane są Bogu cechy cielesne. Otóż, trzeba wiedzieć, że będąc ludźmi spowitymi w to grube nasze ciało, nie jesteśmy w stanie myśleć czy mówić inaczej o wielkich i niematerialnych sprawach Bożych, jak przez uciekanie się do obrazów, przenośni i symbolów, czerpanych z naszego własnego życia. [...] Usta i mowa to u Boga objawienie jego woli, ponieważ właśnie my ustami i mową wyjawiamy zamysły naszego serca" (Jan Damasceński, Wykład Wiary Prawdziwej, s. 49-51). Obiekcja muzułmanina związana jest z brakiem rozróżnienia pomiędzy sensem dosłownym a przenośnym. Wyjaśnienie lingwistyczne w rozumieniu dosłownym i przenośnym Koranu pojawi się dopiero w następnym pokoleniu, po Janie z Damaszku. Będzie to odpowiedź na potrzebę wyjaśnienia antropomorficznych przedstawień w Koranie. Por. Le Coz, Jean Damascène, s. 165-166.

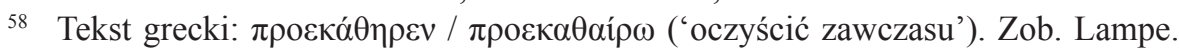
Sura III, 42: „I oto powiedzieli aniołowie: "O Mario! Zaprawdę, Bóg wybrał ciebie

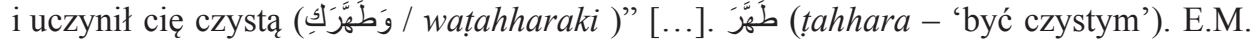
Badawi - M.A. Haleem, Arabic-English dictionary of Qur'anic usage, Leiden - Boston 2008, Brill, 573.

$$
\begin{array}{ll}
59 & \text { Łk 1,35. } \\
60 & \mathrm{Iz} \mathrm{40,12.} .
\end{array}
$$
}


mu: „Odwieczne ${ }^{61}$ Słowo (Lógos) Boga, przez które wszystko zostało stworzone, według świadectwa mojego i twojego Pisma, spłodził ${ }^{62}$ człowieka ze świętego ciała Maryi dziewicy, posiadającego duszę rozumną ${ }^{63}$ i intelekt ${ }^{64}$. Ten [człowiek] jadł, pił i spał. Słowo Boga zaś ani nie jadło, ani nie piło, ani nie spało. [Również] nie zostało ukrzyżowane ani nie umarło. Ale święte ciało, które zostało przyjęte ze świętej dziewicy, [to] ono zostało ukrzyżowane. Widzisz zatem, że Chrystus ma podwójną naturę ${ }^{65}$, ale jedną osobę ${ }^{66}$. W rzeczywistości jedynie odwieczne Słowo Boga po przyjęciu ciała [było] osobą, a nie naturą. [Dlatego] czwarta osoba $^{67}$ nie została dodana do Trójcy Świętej po niewysłowionym zjednoczeniu [Słowa] z ciałem".

\section{(8) [Zaśnięcie Maryi]}

I gdy zapyta cię Saracen: „Ta, którą nazywacie Matką Boga ${ }^{68}$, umarła czy żyje?”, odpowiedz mu: „Ona nie umarła, mając na uwadze to, co podaje Pismo. W świetle wiary, o czym dowodzi Pismo, nie umarła: «Przyszła i na nią naturalna śmierć ludzi, ale nie przez osobiste ograniczenie lub zniewolenie, jak na nas ${ }^{69}$. Bynajmniej daleko od tego! Ale

\footnotetext{
61 Прохı⿱㇒冋vıs ('przed wiekami, wieczne'). Zob. Lampe.

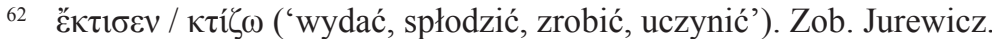

63 ع̋ $\mu \psi v \chi 0 \varsigma$ ('mający rozumną duszę'). Zob. Lampe.

64 Ěvvoos ('posiadać umysł, intelekt'). Zob. Lampe.

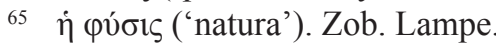

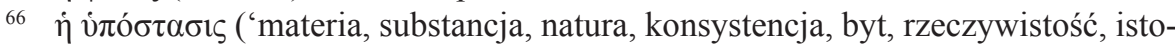
ta'). Zob. Jurewicz.

67 Fragment ten jest świadectwem, że muzułmanie jako czwartą osobę liczyli ludzką naturę Chrystusa. Mówi o tym At-Tabari (IX/X wiek) w swojej polemice antychrześcijańskiej, które z pozycji muzułmańskiego „teologa” wygląda na wielobóstwo. Por. The polemical works of 'Alī al-Țabarī, The history of Christian-Muslim relation, t. 27, red. R. Ebied - D. Thomas, Leiden - Boston 2016, 68: „Pierwsze pytanie, które powoduje [ich] milczenie: Pytamy [bowiem] chrześcijan o kwestię jedności (توحيد/tawhīd) Boga, którą [już] wyjaśniłem, i wiarę, którą już opisałem - czy jest to prawda czy pomyłka? Jeśli

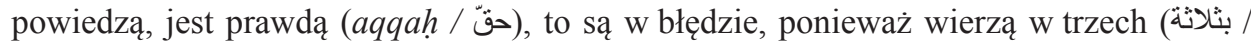

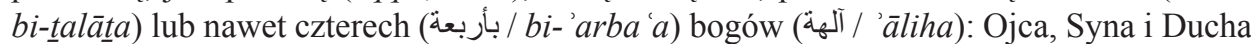
Świętego oraz wiecznego (أزليّ) / 'azaliyy) człowieka, którym jest Jezus Chrystus (przekład autora).

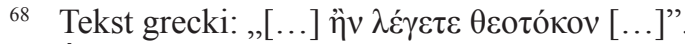

69 Śmierć Dziewicy Maryi nie jest wzmiankowana w Ewangeliach. Zagadnienie zaśnięcia Maryi porusza w swojej homilii XII Andrzej z Krety: In dormitionem sanctissimae

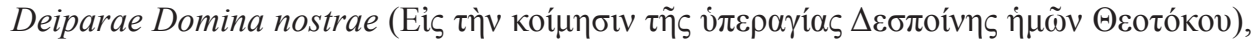


jak się to mówi: „Pierwszego człowieka pochwycił sen i żebro zostało mu usunięte ${ }^{70} \gg "$.

\section{(9) [Kompletność aktu stwarzania]}

Jeżeli Saracen zapyta ciebie: „Oto otrzymałem cios w jakieś miejsce na moim ciele i uderzenie spowodowało ranę, i w ranie narodził się robak. [Powiedz mi,] kto go ukształtował”, odpowiedz mu: „Już to wyjaśniliśmy [wcześniej], że po upływie pierwszych siedmiu dni tworzenia świata nie widzimy niczego takiego, co byłoby stworzone lub ukształtowane przez Boga, ale to na polecenie Boga, który wydał w pierwszych siedmiu dniach, rodzi się to, co jest zrodzone. Po [grzesznym] nieposłuszeństwie ziemia została skazana na [rodzenie] cierni i ostów. I do tej pory, nawet bez zasiania, rodzi ciernie i osty ${ }^{71}$. Dlatego też i nasze ciało zostało skazane i do tej pory rodzi wszy i robaki ${ }^{72}$ ".

\section{(10) [Wyższość Chrystusa nad Janem Chrzcicielem]}

Saracen zadaje wciąż pytania chrześcijaninowi: „Kto jest według ciebie bardziej znaczący: ten, który uświęca, czy ten, który jest uświęcany?". Chrześcijanin, znając wrogośćc ${ }^{73}$ tego pytania, odpowiada: „Wiem co chcesz powiedzieć".

Saracen: Jeśli wiesz, oznajmij mi to!

PG 97, 1046-1072. Jan preferuje opowieść o zaśnięciu Marii prawdopodobnie dlatego, że widzi różnicę pomiędzy śmiercią sług Boga (proroków) a Matki Boga (Dziewicy Maryi), przez co chce podkreślić, że śmierć została pokonana. Jan Damasceński podważa zatem śmierć Maryi, ignorując podstawowe prawdy natury jak śmierć ciała i jego rozkład. Wierzy, że Maryja musi w pewien sposób „naśladować” swojego zmartwychwstałego Syna. Le Coze sugeruje, że Jan w swojej interpretacji idzie za daleko, zrównując teksty biblijne z tekstami Ojców Kościoła - tekstem Andrzeja z Krety. Por. Le Coz, Jean Damascène, s. 177-178.

$70 \operatorname{Rdz} 2,21$.

71 Rdz 3,18.

72 Cały ten punkt jest uzupełnieniem do punktu 1.1 („Kreacja a prokreacja”).

73 Tekst grecki: हैvo $\pi \lambda$ ov od Ěvo $\pi \lambda \circ \varsigma$ ('uzbrojony, zbrojny, zawierający zbrojnych żołnierzy, wojowników’). Zob. Jurewicz. Termin w tekście greckim ma konotacje wojskowe, trudne do dosłownego oddania w języku polskim w taki sposób, aby zdanie posiadało sens. Ten sam motyw poruszany jest przez Teodora Abu Qurra w Opusculum (XXXVIII, PG 97, 1593-1596). 
Chrześcijanin mówi: „Jeśli powiem tobie, że ten, który uświęca, jest większy od tego, który jest uświęcany”, ty mi powiesz: „Odejdź adorować Jana Chrzciciela, ponieważ ochrzcił i uświęcił twojego Chrystusa!”.

Saracen: To jest to - mówi - co ja chciałem ci powiedzieć.

Chrześcijanin powiedział do Saracena w zagadkowy ${ }^{74}$ sposób: „Kiedy pójdziesz do łaźni w towarzystwie swojego sługi i jesteś przez niego myty i oczyszczany, o którym powiesz, że jest większy: ten skromny sługa, nabyty za srebro, czy ty, który zostałeś przez niego oczyszczony i który jesteś jego mistrzem?".

Saracen odpowiada chrześcijaninowi: „Mówię, że ja sam, nabywający, jestem większy od tego, którego nabyłem".

Chrześcijanin odpowiedział: „Raduję się w Bogu! W ten sposób i ja sądzę o Janie jako o słudze, który pomagał Chrystusowi w Jordanie, usługując mu w czasie chrztu, zmiażdżył głowy złych demonów, które czaiły się tam".

Saracen bardzo zaskoczony i zmieszany, nie mając nic więcej do powiedzenia, odszedł, niczego już nie kwestionując.

Z języka greckiego przełożył oraz wstępem i komentarzem opatrzył Łukasz Karczewski ${ }^{75}$

${ }^{74} \alpha \mathrm{iv} \gamma \gamma \mu \alpha \tau \omega \delta \tilde{\omega} \varsigma$.

75 Doktorant w Instytucie Historii na Wydziale Nauk Historycznych i Społecznych UKSW, e-mail: karczewski-lukasz@wp.pl, ORCID: 0000-0001-5654-040X. 